\title{
Peutz-Jeghers-heilkenni með garnasmokkun
}

\section{Gísli Gunnar Jónsson Jórunn Atladóttir}

Höfundar eru læknar á skurð̋ækningasviði Landspítala Hringbraut.

Fyrirspurnum svarar Gísli Gunnar Jónsson, gisligun@landspitali.is

Birt með leyfi sjúklingsins.

\begin{abstract}
Á G R I P
Hér er lýst tilfelli sjúklings með staðfest Peutz-Jeghers-heilkenni á grundvelli jákvæðrar vefjagreiningar samhliða litabreytingum á vörum. Pessi sjúklingur greindist ekki fyrr en hann fékk innsmokkun á mjógirni. Hægt hefði verið að greina hann fyrr á ævinni vegna fyrrgreindra litabreytinga og sögu um tíð kviðverkjaköst.
\end{abstract}

doi.org/10.17992//bl.2018.10.200

á 25-30 cm bili neðarlega í kvið (mynd 1).

Gerð var kviðarholsaðgerð par sem garnasmokkun sást á um pað bil hálfum metra af smágirni. Leyst var úr garnasmokkuninni og fyrirferð í smágirninu preifaðist og var vendipunktur garnasmokkunarinnar (mynd 2). Gert var hlutabrottnám á smágirni og fyrirferðin fjarlægð. Vefjagreining sýndi sepa með einkennandi útlit fyrir sepamyndun í Peutz- Jeghers-heilkenni og engin merki um æxlisvöxt í aðlæg-

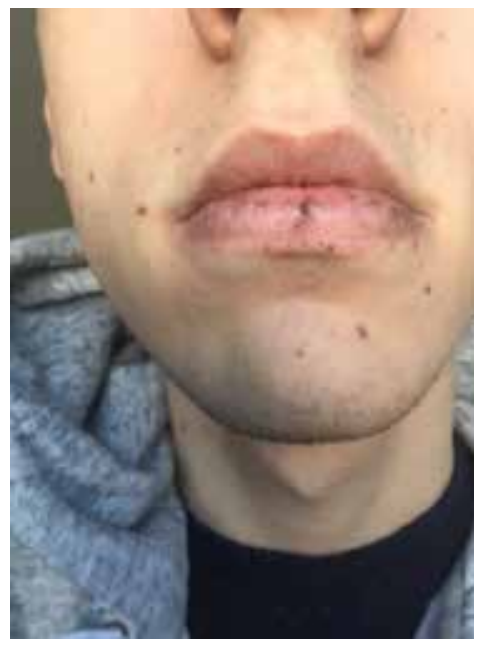

Mynd 3. Sjá má blágráar og brúnar litabreytingar á neðri vör sjúklings. ógleði og uppkasta sem höfðu varað í tvær klukkustundir. Hann var illa haldinn af verkjum en kviðurinn var pó mjúkur og án preifieymsla við fyrstu skoðun og garnahljóð voru eðlileg. Verkirnir versnuðu hratt, maðurinn var kaldsveittur og fölur en ítrekuð kviðskoðun var eðlileg. Hækkun á hvítum blóðkornunum var væg (13,5 púsund) en C-reaktíft prótein var eðlilegt. Fengin var tölvusneiðmynd af kvið sem sýndi garnasmokkun

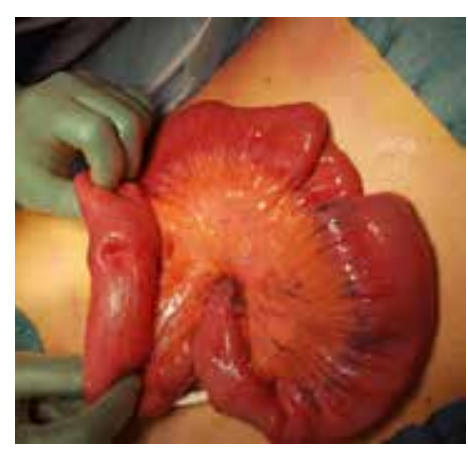

Mynd 2. Tekin í aðgerð. Sýnir fyrirferð í smágirni eftir að búið var að leysa úr garnasmokkun. um eitlum. Pegar sjúklingur var skoðaður með tilliti til pessa sjúkdóms sáust vel litabreytingar á vörum sem fjölskylda sjúklingsins hafði tekið eftir hjá honum í æsku (mynd 3). Auk pess voru tvær litabreytingar til staðar í slímhúð munnhols en engar litabreytingar fundust á iljum eða lófum. Rannsókn hjá erfðaráðgjöf staðfesti að um Peutz-Jeghers-heilkenni væri að ræða, líklegast sporadísk erfðabreyting par sem ættarsaga var engin. Gerð var segulómmynd af kviði til eftirlits sem sýndi ekki fram á æxlisvöxt. Fyrirhugað er krabbameinseftirlit með maga- og ristilspeglun á eins til tveggja ára fresti auk árlegrar skimunar með segulómun af eistum og á eins til tveggja ára fresti af brisi. 


\section{Umræða}

Peutz-Jeghers-heilkenni var fyrst lýst árið 1921 af Jan L. Peutz- og svo að nýju árið 1944 af Harold J. Jeghers. Heilkennið er sjaldgæfur ríkjandi A-litninga erfðasjúkdómur með háa tíðni svipgerðar sem lýsir sér í sepamyndun í meltingarvegi auk litabreytinga á húð og slímhúð.-3 Fjölskyldusaga er til staðar í um 55\% tilfella auk pess sem tíðni krabbameins í fyrstu gráðu ættingjum er hærri en í almennu pýði og er pess vegna mælt með að pessir einstaklingar gangist undir krabbameinseftirlit og nánir ættingjar peirra fái erfðaráðgjöf með tilheyrandi genaprófun. ${ }^{4-6}$

Algengi Peutz-Jeghers-heilkennis er 1:8300 til 1:200.000 og er enginn munur milli kynja. Heilkennið er einkennalaust í $50 \%$ tilfella við greiningu. Algengustu fylgikvillar sjúkdómsins eru: garnasmokkun, blæðing frá sepum með fylgjandi blóðskorti og stífla í meltingarvegi vegna sepa. Meðalaldur fyrstu einkenna frá meltingarfærum er 13 ár. Allt að 69\% einstaklinga með Peutz-Jeghers-heilkenni fá garnasmokkun á lífsleiðinni og pá oftast í dausgörn. Í um pað bil 90\% tilfella lýsa sjúklingar pá miklum kviðverk en í 40\% tilfella eru peir með einkenni smágirnisstíflu. Einnig geta peir verið með blóð í hægðum, niðurgang og blóðskort.,8-11

Sepamyndunin er í formi vaxtarvillusepa (hamartomatous polyps) og getur komið fram hvar sem er í meltingarveginum en er algengust í smágirni. ${ }^{8,12}$ Separnir geta einnig myndast utan meltingarvegar, til dæmis í pvagblöðru, nýrnaskjóðum, lungum og nefkoki. Sjúklingar með Peutz-Jeghers-heilkenni eru í aukinni hættu að mynda krabbamein sökum sepamyndunar en 38-66\% peirra greinast með krabbamein í meltingarvegi á ævinni. ${ }^{1}$

Yfir 95\% sjúklinga með Peutz-Jeghers-heilkenni eru með fyrrnefndar litabreytingar. Pær koma oftast fram á unga aldri og eru jafnvel til staðar við fæðingu. Pá eru pær helst á vörum, við munn og í munnslímhúð en einnig í lófa, undir iljum, við nef, endaparm og kynfæri. Um er að ræða blá-gráa eða brúna fleti, 1-5 mm að stærð, sem koma fram snemma á æviskeiði og eru ekki taldir vera forstig krabbameins. ${ }^{8,13}$ Sjúklingurinn í okkar tilfelli reyndist vera með litabreytingar í kringum munn, á vörum og einnig í munnslímhúð, en ekki á iljum eða lófum.

Sjúklingur skal uppfylla eitt af eftirfarandi skilgreiningaratriðum til að uppfylla klínísk greiningarskilmerki fyrir Peutz-Jeghersheilkenni: ${ }^{14,15}$
1. Tveir eða fleiri separ sem samræmast Peutz-Jeghers-heilkenni á vefjagreiningu.

2. Fjölskyldusaga um Peutz-Jeghers-heilkenni auk sepa hjá sjúklingi sem samræmist heilkenninu á vefjagreiningu.

3. Fjölskyldusaga um Peutz-Jeghers-heilkenni með litabreytingum hjá sjúklingi sem samræmast heilkenninu.

4. Einkennandi litabreyting ásamt sepa sem samræmist PeutzJeghers-heilkenni á vefjagreiningu.

Sjúklingur í okkar tilfelli var með einkennandi litabreytingar ásamt sepa sem samræmdist Peutz-Jeghers-heilkenni á vefjagreiningu og uppfyllti pví skilmerki Alpjóðaheilbrigðisstofnunarinnar (WHO) fyrir sjúkdóminn.

Einstaklingar sem greinast með heilkennið eiga að gangast undir krabbameinseftirlit sem felur í sér eftirfarandi: ${ }^{6}$

- Maga- og ristilspeglun auk speglunar, hylkisrannsóknar eða segulómunar á smágirni frá 8 ára aldri. Pessar rannsóknir skal framkvæma á priggja ára fresti ef separ eru til staðar. Annars skal endurtaka rannsókn við 18 ára aldur.

- Klínísk brjóstaskoðun á 6 mánaða fresti frá 18 ára aldri auk brjóstamyndatöku árlega frá 25 ára aldri.

- Skoðun á kvenlíffærum með ómun, grindarbotnsskoðun með stroki og CA-125 mælingu í blóði árlega frá 18-20 ára aldri.

- Segulómskoðun, ómun í speglun eða segulómun af gall- og brisgangi á eins til tveggja ára fresti frá 30 ára aldri.

- Klínísk eistnaskoðun, auk ómunar ef klínísk skoðun er afbrigðileg, árlega frá fæðingu eða unglingsárum.

\section{Niðurstaða}

Niðurstaðan sem draga má af pessu tilfelli er að ávallt skal hafa Peutz-Jeghers-heilkenni í huga ef einstaklingur hefur fengið endurtekna kviðverki frá barnæsku með fyrrnefndum litabreytingum. Sér í lagi ef hann hefur fengið blæðingu um endaparm eða reynist vera með blóðskort. Рað væri hagur í pví að ná pessum sjúklingum í viðeigandi eftirlit áður en peir fá smágirnisstíflu eða garnasmokkun. 


\section{Heimildir}

1. van Lier MG, Wagner A, Mathus-Vliegen EM, Kuiper EJ, Steyerberg EW, van Leerdam ME. High cancer risk in Peutz-Jeghers syndrome: a systematic review and surveillance recommendations. Am J Gastroenterol 2010; 105: 1258-64; author reply 65

2. Georgescu EF, Stänescu L, Simionescu C, Georgescu I Ionescu R, Florescu G. Peutz-Jeghers syndrome: cas report and literature review. Rom J Morphol Embryol 2008; 49: 241-5

3. Mozaffar M, Sobhiyeh MR, Hasani M, Fallah M. PeutzJeghers syndrome without mucocutaneous pigmentation: a case report. Gastroenterol Hepatol Bed Bench 2012; 5 : 169-73.

4. Sökmen HM, Ince AT, Bölükbas C, Kilic G, Dalay R Kurdas OO. A Peutz-Jeghers syndrome case with iron deficiency anemia and jejuno-jejunal invagination. Turk J Gastroenterol 2003; 14: 78-82.

5. Schulmann K, Pox C, Tannapfel A, Schmiegel W. The patient with multiple intestinal polyps. Best Pract Res Clini Gastroenterol 2007; 21: 409-26.
6. McGarrity TJ AC, Baker MJ. Peutz-Jeghers Syndrome. Seattle (WA): University of Washington, Seattle, 1993-2018.

7. Lindor NM, Greene MH. The concise handbook of family cancer syndromes. Mayo Familial Cancer Program. J Natl Cancer Inst 1998; 90: 1039-71

8. Utsunomiya J, Gocho H, Miyanaga T, Hamaguchi E, Kashimure A. Peutz-Jeghers syndrome: its natural course and management. Johns Hopkins Med J 1975; 136: 71-82.

9. Hinds R, Philp C, Hyer W, Fell JM. Complications of childhood Peutz-Jeghers syndrome: implications for pediatric screening. J Pediatr Gastroenterol Nutr 2004; 39: 219-20.

10. van Lier MG, Mathus-Vliegen EM, Wagner A, van Leerdam ME, Kuipers EJ. High cumulative risk of intussusception in patients with Peutz-Jeghers syndrome: time to update surveillance guidelines?Am J Gastroenterol 2011; 106: 940-5.

11. Pétursdóttir K, Rósmundsson P, Hannesson PH, Möller PH. Garnasmokkun hjá börnum á Íslandi. Læknablaði 2013; 99: 77-81.
12. Jeghers $\mathrm{H}$, Mc $\mathrm{KV}$, Katz $\mathrm{KH}$. Generalized intestinal polyposis and melanin spots of the oral mucosa, lips and digits; a syndrome of diagnostic significance. $\mathrm{N}$ Engl J Med 1949; 241: 1031-6.

13. Gammon A, Jasperson K, Kohlmann W, Burt RW. Hamartomatous polyposis syndromes. Best Pract Res Clin Gastroenterol 2009; 23: 219-31.

14. Aaltonen LA. Hereditary intestinal cancer. Semin Cancer Biol 2000; 10: 289-98.

15. Aretz $S$, Stienen $D$, Uhlhaas $S$, Loff $S$, Back $W$ Pagenstecher C, et al. High proportion of large genomic STK11 deletions in Peutz-Jeghers syndrome. Hum Muta 2005; 26: 513-9.

16. Latchford AR, Neale K, Phillips RK, Clark SK. Juvenile polyposis syndrome: a study of genotype, phenotype, and long-term outcome. Dis Colon Rectum 2012; 55: 1038-43.

17. Syngal S, Brand RE, Church JM, Giardiello FM, Hampe $\mathrm{HL}$, Burt RW, et al. ACG clinical guideline: Genetic testing and management of hereditary gastrointestinal cance syndromes. Am J Gastroenterol 2015; 110: 223-62; quiz 63.

Barst til blaðsins 16. apríl 2018, sampykkt til birtingar 3. júlí 2018.

\section{ENGLISH SUMMARY}

\section{Peutz-Jegher syndrome presenting with intussusception}

\section{Gísli Gunnar Jónsson ${ }^{1}$ Jórunn Atladóttir ${ }^{1}$}

In this case report we describe a patient with a confirmed diagnosis of Peutz-Jegher syndrome. A diagnosis made from a positive tissue sample from the small bowels and characteristic hyperpigmentation on the patient's lips. This particular patient wasn't diagnosed till he got intussusception which required an operation. There's a possibility that the diagnosis could have been made earlier in the patient's life because of the hyperpigmented macules on his lips in addition to frequent abdominal pain.

${ }^{1}$ Surgical unit at Landspitali, University Hospital, Iceland.

Key words: intussusception, hyperpigmentation, Peutz-Jegher syndrome.

Correspondence: Gísli Gunnar Jónsson, gisligun@landspitali.is 